УАK 316.728

ББК 60.564.0

DOI 10.22394/1682-2358-2017-6-90-94

D.V. Zotkin, post-graduate student of the Communication and Management Sociology Department, Saratov State University named after N.G. Chernyshevsky

\section{THE DEVELOPMENT OF RESIDENTS' LEISURE ACTIVITY IN TERMS OF ACCESS TO WATER RESOURCES OF SARATOV}

The development of leisure activity of urban residents in terms of access and consumption of water resources by the example of Saratov is considered. The evidence of expert surveys have shown that today it is an important problem in the socio-economic life and development of the city.

Key words and word-combinations: water resources, city, leisure activities of citizens.
A.B. Зоткин, аспирант кафедри соииологии коммуникаиий и упраљления Саратовского государственного научно-исследовательско20 университета им. Н.Г. Черньпиељского (email: zotkind@inbox.mu)

\section{РАЗВИТИЕ АОСУГОВОЙ АКТИВНОСТИ ГОРОЖАН В АСПЕКТЕ АОСТУПА K BOAHЫM PECУРCAM CAPATOBA}

Аннотацияя. Рассматривается развитие досуговой активности горожан в аспекте доступа и потребления водных ресурсов на примере города Саратов. На основе данных экспертных опросов актуализируются проблемы социально-экономической жизни современного города.

Ключевые слова и словосочетания: водные ресурсы, город, досуговая активность горожан.

Аной из важнейших особенностей городского пространства Саратова явмяется наличие реки Волги. С момента своего основания Саратов выполнял функции военной крепости, опорного пункта государства и крупной пристани Аля посольских, купеческих и военных судов. Город стал портом Аля проходящих мимо караванов судов. В настоящее время акватория Волги используется в различных целях: рыбоводства, рыболовства и судоходства; водоснабжкения и орошения каналов Балаковской, Комсомольской, Приволжской и Энгельсской оросительных систем [1].

В условиях развития рекреационных 
ресурсов в целях улучшения туристической привлекательности города остро проявилась проблема развития Аосуговой активности горожан. Инфраструктура досуга на реке Волге оказалась Аостаточно неразвитой по причине отсутствия санкционированных мест Аля купания и низкого функционирования внутреннего водного транспорта [2]. В настоящее время досуг становится одним из показателей развития городского общества, средством интеграции и самореализаџии его практик. В России досуг является неотъемлемым видом деятельности как Аля отдельных индивидов, так и Аля общества в целом. УАовлетворение духовных потребностей, физических, мичных, а также социальных - основная форма досуга. Это характерно и дия досуга в аспекте потребления водных ресурсов [3, с. 150] .

Представляется целесообразным начать историю вопроса с изучения Понятие «Аосуг» в экономическом и соџиологическом аспектах изучалось в работах таких авторов, как Аж. Кемли, М. Каплин, А.И. Михайцова, С.Г. Струмимин, Б.А. Грушин, П.П. Маслов. Развитие Аосуговой активности в соџиальном пространстве города играет важную роль Аля удовлетворения населения, а также отдельных социальных групп, индивидов в моральных, нравственных и соџиально-экономических интересах. С нашей точки зрения, понятие Аосуга означает занятие тем или иным видом деятельности, вызывающей интерес горожан, определенной соџиальной группы населения, а также его отдельных индивидов. Горожкане в свободное от работы время могут выбрать определенный виА социальной активности (Аосуга) с целью удовлетворения нравственных, физических, моральных и духовных потребностей.

Неоспоримой теоретической заслугой Аж. Кемли и М. Каплина явмяется то, что они осуществили дифференциацию в Аосуговой сфере, разделив его на свободное время, отводимое на соџиальные и антисоџиальные, цеми и бесцельное время. УАовольствие - это источник счастья, в какой-то степени имеющий гедонистический характер. Аیя досуга характерно отсутствие скуки и получение максимального удовольствия как основы мотивации в Аосуговой активности. В рамках Аосуга восстанавливаются силы, происходит рекреация ресурсов (физических, психических, иных) человека, которые затем вновь тратятся в основном виде его Аеятельности, например профессиональной, где, как правило, осуществцяется самореализация. Время Аля Аосуга, по мнению ученых, это Аискреционное (используемое по собственному усмотрению), или свободное время, не требующее подлержания биологических функций, экономического благосостояния или выполнения соџиокультурных обязательств [4]. Развитие водного Аосуга, с нашей точки зрения, включает и пропаганду здорового образа жизни населения.

А.И. Михайлова приводит следующее определение: «Аосуг - это совокупность занятий, выполняющих функщию восстановления физических и психических сил человека. Он включает в себя занятия, связанные с потреблением культурных ценностей индивидуального, комлективного ици публично-зрелищного характера, и занятия, связанные с отдыхом и развлечением, в том числе это физически активный и пассивный отдых, общение, развиечение в компании, пустое времяпровождение, прогулки, занятия антикультурного характера 
(азартные игры, пьянство и другое), случайные занятия без целей, жеканий и потребностей» [5, с. 302] .

С.Г. Струмилин необходимое время рассматривает как производственный труа в общественном и Аичном хозяйствах; Аомашний труА (в семье); потери времени (в частности, поездки на работу и обратно); физиологические потребности (еда, сон). Свободное время автором трактуется как физическое развитие (спорт, туризм); культурная самодеятельность (посещение объектов культурной инфраструктуры, чтение); культурный отАых (Аомашний культурный досуг, посещение культурно-массовых мероприятий; прием и походы в гости, и безАеятельный отАых) [6, с. 284].

В определениях понятия "досуг» наиболее распространено деление его на активный и пассивный. По мнению Б.А. Грушина, «существует принципиальная разница межау так называемым активным и пассивным способами опреАеления Аосуга» [7, с. 140]. Соџиологи не пришии к общему мнению о том, какой тип Аосуга следует отнести к активному или пассивному. П.П. Маслов к активным занятиям причисляет чтение, слушание радио, просмотр телепередач. В.Б. Ананайчук считает, что к пассивному отдыху следует отнести: прогулки, посещение парков [8, с. 100].

Большинство отечественных ученых сходятся в определении досуга как совокупности видов деятельности, которая предназначена Аля удовцетворения

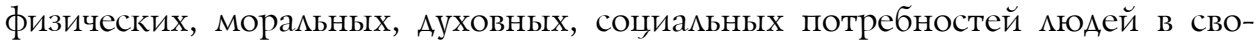
бодное время. Занятия на досуге служат как отдыху, так и развитию кичности, удовлетворению потребности в развлечениях и общении [9, с. 132] . На наш взгляА В.И. Аобренькова и А.И. Кравченко, «досуг - это время мюбительской деятельности, просмотр телепереАач, чтение книг, посещение театров» [10, с. 16].

С нашей точки зрения, досугом следует считать выбор определенного вида соџиальной активности индивида, направценного на удовлетворение своих моральных, физических и духовных потребностей, к которым также относится и организация досуга потребления водных ресурсов. Аля жителей города Саратова Аосуг и потребцение водных ресурсов в силу неразвитости соответствующей инфраструктуры явцяется одной из важнейших проблем несмотря на близость Волги.

Аля изучения досуговых практик в рамках использования водного транспорта и водных ресурсов нами было проведено экспертное интервьюирование. В опросе приняли участие владельцы маломерных водных транспортных еАиниџ, руководство и работники Саратовского речного транспортного преАприятия, работники Яхт-клуба «ААмирам». В результате проведения опроса по анкете: «Последствия утраты внутреннего водного транспорта в Саратове» выявлены факты негативных последствий в экономическом развитии города. Так, согласно мнению директора по персоналу Саратовского речного транспортного предприятия, в результате утраты внутреннего водного транспорта сократится строительство, так как саратовский порт основной поставщик материалов Аля строительства дорог и жилищных комплексов. По мнению владельцев маломерных судов, утрата данной инфраструктуры приведет к не- 
гативным последствиям в развитии городского туризма. Проблема низкого уровня функщионирования внутреннего водного транспорта в г. Саратове усугубмяется решением властей перенести модочные станции на окраину города - в Заводской район. Причиной переноса Аодочных станџий явцяется продмение городской набережной, в результате чего затронуты кичные интересы владельцев маломерных судов. По словам представителей данной группы населения, перенос приводит к ухудшению условий пользования ими воАного транспорта, что подтверАилось в ходе проведения экспресс-опросов.

В современном российском городе существует множество различных возможностей и видов проведения досуговой деятельности благодаря соџиальным; экономическим и культурным особенностям его пространства. Гцавной особенностью географического расположения города Саратова является река Волга. Как следствие, вопрос о потреблении водных ресурсов - один из ключевых в развитии города как в экономическом, так и в соџиальном аспекте.

По мнению депутата Саратовской обцастной Аумы 3.М. Самсоновой, причиной отсутствия отраслей хозяйства, связанных с инфраструктурой потребления водных ресурсов, является загрязненность реки, вследствие строительства гидроэлектростанций [11]. В ходе проведения социологического опроса: на вопрос «Каков, на ваш взгляА, уровень проведения досуговой активности на реке Волге в Саратове?» получены в основном неудовлетворительные оџенки. В пример приводилась Самара: «В городе везде пляж. Можно в мюбое время искупаться и позагорать». Недовольны и владельцы маломерных судов, отмечающие недостаток пляжей в Саратове. Аиректор Яхт-кцуба «ААмирал» отметил, что данная проблема актуальна Аля территории всей области. ОАна из причин этого застроенная береговая миния закрывающая доступ к реке.

По сообщению Роспотребнадзора, за время метнего периода 2016 г., разрешение на использование водного объекта получиц только один саратовский пляж - Городские пески. Остальные прибрежкные зоны подлежат санитарной очистке и благоустройству [12]. При этом, в ходе проведения опроса работников Саратовского речного транспортного предприятия и владельцев маломерных судов было выявлено, что и этот пцяж имеет неудобное месторасположение, особенно Аля детей и мюдей преклонного возраста, - межкА Саратовом и Энгельсом.

Согласно формуле франџузского философа и соџиолога А. Аефевра «право на город» [13], право мюдей на городскую жкизнь вкмючает и потребление водных ресурсов. Аля жителей Саратова проведение досуговой деятельности на реке является неотъемлемым и исторически сложившимся, поэтому необходимость создания и улучшения инфраструктуры потребления водных ресурсов более чем актуацьна. В соџиацьном пространстве города сталкиваются интересы разных групп населения, что нередко приводит к повышению уровня соџиальной напряженности и конфликтам. Предупреждение и разрешение их - серьезная практическая задача, с которой сталкивается администрация ююбого города, и ее решение Аолжно базироваться на серьезной исследовательской базе, отражающей состояние и динамику соџиальных отношений в пространстве современного города. В связи с этим вопросы методологии 
исследования соџиального пространства современных городов становятся все более востребованными [14, с. 12].

В широком смысле под инфраструктурой следует понимать всю совокупность объектов (материальных и нематериальных), которые обеспечивают Аеятельность социума ици его отдельной части. Пространственная структура города, безусловно, включает в себя наличие водного объекта или близость к нему - мощного фактора развития города. Проведение досуга на реке дия городского населения Саратова - это не только исторически сложившееся и Аюбимое время проведение Аосуговой Аеятельности, но и мощный ресурс развития спортивно-оздоровительного отдыха. На наш взгляА, нацичие высокого уровня потребления водных ресурсов в городском пространстве является источником экономического развития городской среды (функционирование внутреннего водного транспорта) и соџиокуиьтурного развития (проведение горожанами Аосуга на воде, рыболовство, водный туризм).

\section{Библиографический список}

1. Энциклопедия Саратовского края (в очерках, событиях, фактах, именах). 2-е изд., перераб. Саратов, 2011.

2. Акаев Д.В., Шугаев А.А. Туристическая привлекательность Саратовской области (по материалам эмпирического исследования) // Управленческое консультирование. 2017. № 4 (100). C. $146-151$.

3. Маршак А.Л. Социология культурно-духовной сферы. М., 2007.

4. Кравияова O.A. Рекреационный досуг как предмет научного анализа // Вестник ЧГАКИ. 2013. № 3 (35). С. 158-162.

5. Михайлова Л.И. Социология культуры: учебное пособие. М., 2006.

6. Струмилин С.Г. Проблемы экономики труда. М., 1982.

7. Грушин. Б. Свободное время. Актуальные проблемы. М., 1967.

8. Артемов В.А. Социальное время. Проблемы изучения и использования. Новосибирск, 1987.

9. Российская социологическая энциклопедия / под общ. ред. Г.В. Осипова. М., 1998.

10. Добреньков В.И., Кравченко А.И. Фундаментальная социология: в 15 т. Т. 7: Человек. Индивид. Личность. М., 2005.

11. Спасем Волгу вместе! URL: http://saratov.spravedlivo.ru/005145930-001207.html

12. Роспотребнадзор разрешает открыть только один саратовский пляж. URL: http://www. vzsar.ru/news/2016/06/10/rospotrebnadzor-razreshaet-otkryt-tolko-odin-saratovskii-plyaj.html

13. Бедаш Ю.А. Концепция социального пространства Анри Лефевра // Вестник ТГПУ. 2012. № 11 (126). C. 219-224.

14. Социальное пространство современного города / под. ред. Г.Б. Кораблевой, А.В. Меренкова. Екатеринбург, 2015. 